\title{
Analisis Strategi Penyaluran Dana Zakat, Infak, Sedekah (ZIS) dan Tingkat Inflasi Terhadap Pertumbuhan Ekonomi Di Indonesia Pada Periode 2015-2019
}

\author{
Sarah Hasanah Qoyyim, Sisca Debyola Widuhung \\ Program Studi Manajemen, Fakultas Ekonomi Dan Bisnis, Universitas Al-Azhar Indonesia, \\ Jl. Sisingamangaraja No.2, Kota Jakarta Selatan, 12110 \\ e-mail: sisca.debyola@uai.ac.id
}

\begin{abstract}
Abstrak - Penelitian ini bertujuan untuk mengetahui pengaruh Penyaluran Dana ZIS dan Tingkat Inflasi terhadap Pertumbuhan Perekonomian Di Indonesia periode 2015-2019 serta mengetahui strategi yang digunankan BAZNAS dalam menyalurkan dana ZIS sehingga dapat mempengaruhi pertumbuhan perekonomian di Indonesia. Sampel yang digunakan dalam penelitian ini adalah dengan menggunakan laporan bulanan Dana ZIS dan Inflasi selama 5 tahun atau 60 buah sampel. Metode penelitian yang digunakan dalam penelitian ini adalah metode regresi linier berganda dengan menggunakan data panel. Teknik analisis yang digunakan yaitu analisis regresi dengan menggunakan bantuan software SPSS 23.Berdasarkan hasil analisis regresi dengan tingkat signifikan 95\% maka hasil penelitian ini menunjukan bahwa variabel Dana ZIS memiliki pengaruh yang signifikan secara parsial terhadap pertumbuhan perekonomian di Indonesia, sedangkan variabel Inflasi tidak memiliki pengaruh secara parsial terhadap pertumbuhan perekonomian di Indonesia. Variabel Dana ZIS dan Inflasi memiliki pengaruh signifikan secara simultan terhadap pertumbuhan perekonomian di Indonesia. Untuk meningkatkan perekonomian Indonesia, BAZNAS melakukan penyaluran dana ZIS yang akan disalurkan kepada 8 golongan penerima zakat.
\end{abstract}

Kata Kunci : Dana ZIS, Inflasi, dan Pertumbuhan Perekonomian.

Abstract - This study aims to determine the effect of ZIS (Zakat, Infak, and Sedekah) Funds Distribution and Inflation Rate on Economic Growth in Indonesia in theperiod of 2015-2019 and to find out the strategies used by the National Amil Zakat Agency (BAZNAS) in channeling ZIS funds so as to influence economic growth in Indonesia. The sample used in this study is to use the ZIS Fund and Inflation monthly report for 5 years or 60 samples. The research method used in this study is the method of multiple linear regression using panel data. The analysis technique used is regression analysis using SPSS 23 software. Based on the results of regression analysis with a significant level of $95 \%$, the results of this study indicate that the ZIS Fund variable has a significant influence partially on economic growth in Indonesia, while the Inflation variable has no partial effect on economic growth in Indonesia. The ZIS and Inflation Fund variables have a significant simultaneous effect on economic growth in Indonesia. To improve the Indonesian economy, Badan Amil Zakat Nasional (BAZNAS) distributes ZIS funds which will be distributed to 8 groups of recipients of zakat. This is done so that people who fall into the 8th category of the recipient of zakat can get a decent living and can directly or indirectly contribute to economic growth in Indonesia.

Keywords: ZIS Funds, Inflation, and Economic Growth 


\section{PENDAHULUAN}

$P^{-}$ ertumbuhan ekonomi merupakan suatu proses yang terjadi dalam jangka waktu yang panjang atau dapat diartikan sebagai suatu proses pertumbuhan output perkapita jangka panjang yang terjadi apabila ada kecenderungan (output perkapita untuk naik) yang bersumber dari proses intern perekonomian tersebut (kekuatan yang berada dalam perekonomian itu sendiri), bukan berasal dari luar dan bersifat sementara. Atau dengan kata lain bersifat self generating, yang berarti bahwa proses pertumbuhan itu sendiri menghasilkan suatu kekuatan bagi kelanjutan pertumbuhan tersebut dalam periode-periode selanjutnya. Pertumbuhan ekonomi merupakan suatu proses yang berarti perubahan yang terjadi secara kontinu serta mempunyai unsurunsur pokok dan sifat yaitu usaha untuk meningkatkan pendapatan per kapita, peningkatan pendapatan per kapita itu harus terus berlangsung dalam jangka panjang, dan perbaikan sistem kelembagaan di segala bidang (misalnya ekonomi, politik, hukum, sosial, dan budaya). Pertumbuhan ekonomi dapat tercipta apabila terjadi kenaikan pendapatan perkapita yang terjadi dalam waktu yang relatif panjang.

Pertumbuhan ekonomi merupakan salah satu tolak ukur dari keberhasilan pembangunan ekonomi. Terdapat beberapa faktor yang mempengaruhi terciptanya pertumbuhan ekonomi di suatu negara, salah satu indikator ekonomi makro yang digunakan untuk melihat/mengukur tingkat stabilitas perekonomian suatu negara adalah inflasi. Perubahan dalam indikator ini akan berdampak terhadap dinamika pertumbuhan ekonomi. Dalam perspektif ekonomi, inflasi merupakan fenomena moneter dalam suatu negara dimana naik turunnya inflasi cenderung mengakibatkan terjadinya gejolak ekonomi (Silva, 2013). Inflasi merupakan salah satu faktor yang mempengaruhi pertumbuhan ekonomi yang terjadi di Indonesia. Inflasi adalah kenaikan harga-harga umum yang berlaku dalam suatu perekonomian dari suatu periode ke periode lainnya (Silva, 2013). Tingkat inflasi adalah presentasi kenaikan harga-harga pada suatu tahun tertentu berbanding dengan tahun sebelumnya. Secara sederhana inflasi diartikan sebagai meningkatnya harga-harga secara umum dan terus menerus. Kenaikan harga dari satu atau dua barang saja tidak dapat disebut inflasi kecuali bila kenaikan itu meluas (atau mengakibatkan kenaikan harga) pada barang lainnya. Kebalikan dari inflasi disebut deflasi.

Inflasi ringan apabila kenaikan harga berada di bawah angka $10 \%$ setahun, inflasi sedang antara 10\%-30\% setahun, inflasi berat $30 \%-100 \%$ setahun dan hiperinflasi atau inflasi tak terkendali terjadi apabila kenaikan harga berada di atas $100 \%$ setahun. Inflasi ringan justru dapat mendorong terjadinya pertumbuhan ekonomi. Hal ini karena inflasi mampu memberi semangat pada para pengusaha, untuk lebih meningkatkan produksinya. Pengusaha bersemangat memperluas produksinya karena dengan kenaikan harga yang terjadi para pengusaha mendapat lebih banyak keuntungan. Peningkatan produksi memberi dampak positif lain yaitu, tersedianya lapangan kerja baru kemudian akan berdampak terhadap kemakmuran masyarakat dan akan mendorong terjadinya laju pertumbuhan ekonomi.

Tabel 1.1

Tingkat Inflasi Di Indonesia Periode 2015-2019

\begin{tabular}{|c|c|}
\hline Tahun & Tingkat Inflasi $(\%)$ \\
\hline $\mathbf{2 0 1 5}$ & 3,35 \\
\hline $\mathbf{2 0 1 6}$ & 3,02 \\
\hline $\mathbf{2 0 1 7}$ & 3,61 \\
\hline $\mathbf{2 0 1 8}$ & 3,13 \\
\hline $\mathbf{2 0 1 9}$ & 2,72 \\
\hline
\end{tabular}

Berdasarkan tabel 1.1 dapat disimpulkan bahwa pada tahun 2015 tingkat inflasi sebesar 3,35\% dan dikategorikan sebagai inflasi ringan $(<10 \%$ pertahun). Pada tahun 2016 tingkat inflasi di Indonesia mengalami penurunan dari tahun sebelumnya yaitu sebesar $0,33 \%$ sehingga tingkat inflasi pada tahun 2016 menjadi 3,20\% dan dikategorikan sebagai inflasi ringan. Pada tahun 2017 tingkat inflasi mengalami kenaikan sebesar $0,59 \%$. Untuk tahun 2018 tingkat inflasi mengalami penurunan sebanyak $0,48 \%$ sehingga tingkat inflasinya menjadi $3,13 \%$ dan dikategorikan sebagai inflasi ringan. Untuk tahun 2019 tingkat inflasi mengalami penurunan menjadi 
$2,72 \%$ dan pada tahun ini merupakan tahun dengan tingkat inflasi terendah dalam 10 tahun terakhir.

Terlepas dari kenyataan bahwa untuk menciptakan pembangunan berkelanjutan yang memiliki kompleksitas politik, sosial, etika, dan moral, masalah multi-dimensi tidak dapat diselesaikan dengan pendekatan ekonomi saja (Bayinah, 2017). Dalam perspektif ekonomi islam terdapat faktor yang dapat mempengaruhi pertumbuhan ekonomi di Indonesia yaitu penyaluran dana ZIS. Zakat merupakan rukun Islam yang ketiga dan Allah SWT mewajibkan untuk menunaikan zakat. Zakat dapat membersihkan pelakunya dari dosa dan menunjukan kebenaran imanya, adapun caranya dengan memberikan sebagian harta yang telah mencapai nishab dalam waktu satu tahun kepada orang yang berhak menerimanya (Ghofar, 2010).

Pelaksanaan dana ZIS yang baik dan sesuai dengan ketentuan Al-Qur'an dan Hadits dapat mempengaruhi pertumbuhan perekonomian di suatu negara. Sistem zakat, infak, dan shadaqah dapat memainkan peran penting dalam mendukung pembangunan ekonomi berkelanjutan dan memfasilitasi inklusi keuangan yang lebih baik. Secara konseptual, pengembangan sistem zakat dapat dianggap sebagai pelengkap program pemerintah untuk pengentasan kemiskinan (Khasandy dan Badrudin , 2019). Pada tahun 2018 potensi zakat di Indonesia mencapai 233 Triliun rupiah atau mencapai 3 persen dari PDB Indonesia. Namun pengumpulan zakat baru mencapai 8,2 Triliun rupiah atau sebanding 3.4 persen dari potensi pengumpulan zakat secara nasional.

Dana ZIS yang didapatkan harus disalurkan kepada 8 golongan orang yang berhak menerima zakat, yaitu disalurkan kepada golongan fakir, miskin, amil, muallaf, riqab, gharim, fisabilillah, ibnu sabil. Dengan demikian dapat digunakan untuk meningkatkan kemakmuran sebagian besar masyarakat yang di bawah garis kemakmuran.

Dalam pelaksanaan penyaluran dana ZIS yang dikelola oleh BAZNAS disalurkan dalam bentuk pendistribusian (kuratif dan kedaruratan) dan pendayagunaan (produktif). Penyaluran ini dibagi dalam beberapa kategori sesuai dengan ketentuan yang ada. Ini merupakan salah satu strategi yang diterapkan BAZNAS dalam menyalurkan dana ZIS sehingga dapat memberikan dampak yang baik bagi pertumbuhan perekonomian di Indonesia.

Tabel 1.2

Penerimaan dan Penyaluran Dana ZIS Tahun 2015-2019

\begin{tabular}{|c|c|c|}
\hline Tahun & $\begin{array}{c}\text { Penerimaan } \\
\text { Dana ZIS }\end{array}$ & $\begin{array}{c}\text { Penyaluran } \\
\text { Dana ZIS }\end{array}$ \\
\hline 2015 & $98,473,103,020$ & $66,766,033,36$ \\
\hline 2016 & $111,449,939,35$ & $80,252,586,45$ \\
\hline 2017 & $158,752,636,31$ & $131,917,747,76$ \\
\hline 2018 & $195,092,051,94$ & $175,811,470,98$ \\
\hline 2019 & $296,653,558,8$ & $196,898,478,13$ \\
\hline
\end{tabular}

Berdasarkan tabel diatas dapat dilihat bahwa jumlah dana ZIS yang tersalurkan selalu berfluktuasi. Dana ZIS disalurkan tidak hanya digunakan untuk meningkatkan konsumsi saja tetapi dapat juga dikembangkan menjadi modal kerja yang dapat membantu meningkatkan pendapatan mereka (golongan 8 ashnaf). Jika semakin tinggi pendapatan para mustahik maka akan semakin tinggi pula tingkat konsumsi, jika semakin tinggi tingkat konsumsi maka permintaan terhadap barang dan jasa akan semakin meningkat pula, otomatis produksi barang dan jasa juga akan semakin meningkat dan akan meningkatkan pertumbuhan ekonomi di Indonesia. Berdasarkan marketshare pembayar zakat di BAZNAS pada tahun 2018 yaitu sebanyak 38,500 dengan jumlah penyaluran sebanyak 197 Milyar. Dana yang dihimpun sebanyak 206 Milyar yang disalurkan kepada 636,900 mustahik.

Dilihat dari perspektif ekonomi makro, zakat digunakan untuk meningkatkan permintaan agregat karena pengeluaran besar mustahik. Dengan demikian, itu akan mendorong pertumbuhan ekonomi dan akan mendorong investasi. Ini juga merupakan instrumen kebijakan fiskal yang berfungsi untuk memastikan bahwa kegiatan ekonomi dapat berjalan pada tingkat pemenuhan kebutuhan primer (Bayinah , 2017). Oleh 
karena itu, penelitian ini bertujuan untuk mengetahui pengaruh dari dana ZIS dan inflasi terhadap pertumbuhan ekonomi serta mengetahui strategi yang diterapkan BAZNAS dalam melakukan penyaluran dana ZIS sehingga dapat mempengaruhi pertumbuhan ekonomi di Indonesia pada periode 2015-2019.

\section{TINJAUAN PUSTAKA}

\section{Teori tentang dana zakat, infak, dan sedekah (ZIS)}

Berdasarkan Undang-undang Republik Indonesia Nomor 23 tahun 2011 tentang Pengelolaan Zakat pasal 1 ayat 2, zakat adalah harta yang wajib dikeluarkan oleh seorang muslim atau badan usaha untuk diberikan kepada yang berhak menerimanya sesuai dengan syariat islam. Berdasarkan undangundang Republik Indonesia nomor 23 tahun 2011 tentang pengelolaan zakat, di pasal 1 ayat 3 tentang pengertian infak. Infak adalah harta yang dikeluarkan oleh seseorang atau badan usaha diluar zakat untuk kemaslahatan umat. Infak dikeluarkan berdasarkan kesadaran diri dari setiap orang. Infak berbeda dengan zakat, infak tidak mengenal nisab atau jumlah harta yang ditentukan secara hukum. Infak diberikan kepada siapapun.

Menurut peraturan BAZNAS No.2 tahun 2016, sedekah adalah harta atau non harta yang dikeluarkan oleh seseorang atau badan usaha di luar zakat untuk kemaslahatan umum. Sedekah ditujukan agar perekonomian dikalangan masyarakat miskin dapat membaik.

Sama seperti infak, sedekah mempunyai pengertian yang sama dengan infak. Hal yang membedakan antara infak dan sedekah adalah terletak pada batasan yang diberikan. Infak hanya terbatas pada materi berupa harta, sementara sedekah cakupannya lebih luas bukan hanya materi saja, tapi juga non-materi, seperti senyuman.

\section{Teori Inflasi}

Menurut Bank Indonesia inflasi diartikan sebagai kenaikan harga secara umum dan terus menerus dalam jangka waktu tertentu. Kenaikan harga dari satu atau dua barang saja tidak dapat disebut inflasi kecuali bila kenaikan itu meluas (atau mengakibatkan kenaikan harga) pada barang lainnya. Kebalikan dari inflasi disebut deflasi.
Indikator yang sering digunakan untuk mengukur tingkat inflasi adalah Indeks Harga Konsumen (IHK). Perubahan IHK dari waktu ke waktu menunjukkan pergerakan harga dari paket barang dan jasa yang dikonsumsi masyarakat. Penentuan barang dan jasa dalam keranjang IHK dilakukan atas dasar Survei Biaya Hidup (SBH) yang dilaksanakan oleh Badan Pusat Statistik (BPS). Kemudian, BPS akan memonitor perkembangan harga dari barang dan jasa tersebut secara bulanan di beberapa kota, di pasar tradisional dan modern terhadap beberapa jenis barang/jasa di setiap kota.

\section{Teori Pertumbuhan Ekonomi}

Pertumbuhan ekonomi adalah perkembangan kegiatan dalamm perekonomian yang menyebabkan barang yang diproduksikan dalam masyarakat meningkat. Jadi apabila pertumbuhan ekonomi tinggi maka barang yang akan dihasilkan juga akan meningkat. Hal ini akan meningkatkan tingkat kesejahteraan masyarakat (Herman,2017).

\section{METODE PENELITIAN}

Pendekatan yang digunakan dalam penelitian ini adalah pendekatan kuantitatif dengan metode regresi linier berganda yang diolah menggunakan software SPSS. Dalam penelitian ini data-data yang digunakan adalah data sekunder. Data yang akan dipergunakan ialah data time series bulanan dari tahun 20152019. Data yang dibutuhkan yaitu :

1. Data dana ZIS tahun 2015-2019 bersumber dari Badan Amil Zakat Nasional (pusat.baznas.go.id).

2. Data inflasi Indonesia tahun 20152019 bersumber dari BPS (www.bps.go.id).

3. Data pertumbuhan ekonomi Indonesia tahun 2015-2019 bersumber dari BPS (www.bps.go.id).

Selanjutnya, populasi yang digunakan dalam penelitian ini adalah seluruh lingkup Indonesia dalam kurun waktu lima tahun, yaitu tahun 2015-2019. Seluruh data yang digunakan berupa data bulanan, maka populasnya berjumlah 60 pengamatan. Teknik pengambilan sempel yang digunakan dalam 
penelitian ini adalah sampling jenuh. Sampling jenuh adalah teknik penentuan sampel apabila seluruh anggota populasi digunakan sebagai sampel (Anshori dan Iswati, 2009:106). Teknik Analisis dan Pembahasan menggunakan uji asumsi klasik dan analisis regresi berganda.

\section{HASIL DAN PEMBAHASAN}

\section{Uji Asumsi Klasik \\ Uji Normalitas}

Pada uji One Sample KolmogorovSmirnov (KS-Z) data terdistribusi secara normal apabila nilai Signifikansi $>0,05$. Begitupun sebaliknya apabila nilai Signifikansi $<0,05$ maka artinya data tidak terdistribusi secara normal.

Berdasarkan hasil yang telah didapatkan terlihat bahwa signifikansinya sebesar 0,962. Jadi, nilai signifikannya lebih besar dari 0,05 maka dari itu dapat dikatakan data berdistribusi normal.

\section{Uji Multikolonieritas}

Uji multikolinearitas bertujuan untuk menguji apakah suatu model regresi terdapat korelasi antara variable independent atau tidak. Model regresi yang baik seharusnya tidak memiliki korelasi antarvariabel independen. Apabila nilai Tolerance lebih dari 0,10 dan nilai Varian Inflation Factor (VIF) kurang dari 10,0 maka model tersebut tidak terjadi multikoliniearitas antarvariabel independen dalam model regresi

Hasil penelitian menunjukkan bahwa nilai Tolerance variabel Dana ZIS dan Inflasi lebih besar dari 0,10 dan nilai Variance Inflation Factor (VIF) kurang dari 10,00. Sehingga dapat disimpulkan bahwa tidak ada korelasi antarvariabel independen atau model regresi pada penelitian ini tidak terjadi multikoliniearitas dan model regresi layak digunakan.

\section{Uji Heteroskedastisitas}

Uji heterokedasitas bertujuan menguji apakah dalam model regresi terjadi ketidaksamaan varian dari residual satu pengamatan ke pengamatan yang lain. Jika varian dari residual satu pengamatan ke pengamatan lain tetap, maka disebut homoskedastisitas dan jika berbeda disebut heteroskedastisitas (Ghozali,2016). Jika terdapat pola tertentu pada grafik scatterplot, seperti titik-titik yang memebentuk pola teratur (bergelombang menyebar kemudian menyempit) maka dapat disimpulkan bahwa telah terjadi heteroskedasitas.

Hasil penelitian menunjukkan bahwa pada grafik tersebut terdapat titik-titik yang menyebar dan tidak membentuk pola teratur, maka dapat disimpulkan pada penelitian ini tidak terjadi heteroskedasitas.

\section{Uji Autokorelasi}

Uji autokorelasi digunakan untuk menguji apakah dalam model regresi linier ada korelasi anatara kesalahan pengganggu pada periode $\mathrm{t}$ dengan kesalahan periode $\mathrm{t}-1$. Jika terjadi korelasi, maka dinamakan ada problem autokorelasi. Autokorelasi muncul karena observasi yang berurutan sepanjang waktu berkaitan satu sama lainnya.

Untuk mendeteksi uji autokorelasi dapat dilihat pada nilai Durbin-Watson. Jika nilai Durbin-Watson berada diantara -2 sampai dengan +2 maka tidak terjadi autokorelasi. Pada hasil uji autokorelasi diatas terdapat nilai Durbin-Watson sebesar 0,698, maka tidak terjadi autokorelasi pada data penelitian ini.

\section{Uji Hipotesis \\ Uji t}

Keputusan uji hipotesis secara parsial dilakukan berdasarkan ketentuan sebagai berikut:

1. Apabila tingkat singnifikansi lebih besar dari 5\%, maka dapat disimpulkan bahwa Ho diterima.

2. Apabila tingkat signifikansi lebih kecil dari 5\%, maka dapat disimpulkan bahwa Ho ditolak.

Hasil perhitungan Uji t dalam penelitian ini dapat dilihat pada tabel berikut ini:

Berdasarkan hasil pengolahan data, dapat ditarik beberapa kesimpulan sebagai berikut:

1. Berdasarkan perhitungan t-statistic yang diperoleh adalah 7,819 > t tabel sebesar 2,00247. Dengan nilai signifikan sebesar $0,000<\alpha$ sebsesar 
0,05 sehingga Ho ditolak. Jadi terdapat pengaruh Dana ZIS terhadap pertumbuhan ekonomi di Indonesia periode 2015-2019.

2. Berdasarkan perhitungan t-statistic yang diperoleh adalah sebesar $-1,338$ $<$ t table sebesar 2,00247, dengan nilai signifikan sebesar $0,186>\alpha$ sebesar 0,05 maka Ho diterima. Jadi, tidak terdapat pengaruh inflasi terhadap pertumbuhan ekonomi di Indonesia periode 2015-2019.

\section{Uji F}

Uji $F$ digunakan untuk mengetahui apakah keseluruhan variabel independen berpengaruh secara bersama-sama (simultan) terhadap variabel dependen. Jika nilai sig < 0,05, maka semua variabel independen secara simultan berpengaruh signifikan terhadap variabel dependen.

Berdasarkan hasil pengolahan data dapat dilihat pengaruh simultan variabel independen Dana ZIS dan Inflasi terhadap variabel dependen Pertumbuhan Perekonomian. Dari hasil uji simultan diperoleh nilai $\mathrm{F}$ hitung sebesar 30,629 dengan tingkat signifikansi sebesar 0,000. Berdasarkan nilai signifikansi yang jauh lebih kecil dari 0,05, maka dapat dikatakann bahwa Dana ZIS dan Inflasi secara bersama-sama (simultan) berpengaruh terhadap Pertumbuhan Perekonomian.

\section{Uji Koefisien Determinasi}

Koefisien determinasi (Adjusted $R$ Square) yang terlihat pada tabel berikut mengindikasikan kemampuan persamaan regresi berganda untuk menunjukan tingkat penjelasan model terhadap variabel dependen.

Berdasarkan hasil pengolahan data, besarnya koefisien determinasi ( $R$ Square) adalah 0,518 dapat dijelaskan oleh dua variabel independen yaitu : Dana ZIS dan Inflasi dengan tingkat kemampuan menjelaskan $51,8 \%$ terhadap variabel dependen, sedangkan sisanya 48,2\% (100\% $51,8 \%$ ) dijelaskan oleh variabel lain yang tidak diteliti.

\section{Analisis Regresi Linear Berganda}

Mengacu pada hasil penelitian, dapat diperoleh persamaan regresi linier berganda sebagai berikut:

$$
\mathrm{Y}=11,940+0,155 \mathrm{X} 1-0,620 \mathrm{X} 2+\mathrm{e}
$$

Dimana :

$\mathrm{Y}=$ Pertumbuhan Ekonomi

$\mathrm{X} 1=$ Dana ZIS

$\mathrm{X} 2=$ Inflasi

e $\quad=$ Standard Error

Dari persamaan regresi diatas maka dapat dijelaskan sebagai berikut :

1. Konstanta $\alpha$ sebesar 11,940 dan bertanda positif menunjukkan bahwa pertumbuhan ekonomi akan mengalami peningkatan sebesar 11,940.

2. Koefisien regresi $\beta 1$ variabel dana ZIS tersebut bertanda positif 0,155 yang artinya apabila perubahan dana ZIS naik 1 maka terjadi perubahan pertumbuhan ekonomi akan bergerak kearah yang sama (naik) sebesar 0,155 .

3. Koefisien regresi $\beta 2$ variabel inflasi tersebut bertanda negatif 0,620 yang artinya apabila perubahan tingkat inflasi naik 1 maka terjadi perubahan pertumbuhan ekonomi, akan bergerak kearah yang berbeda (turun) sebesar 0,620 .

\section{Strategi yang diterapkan BAZNAS dalam menyalurkan dana ZIS sehingga dapat mempengaruhi pertumbuhan perekonomian di Indonesia.}

Berdasarkan data yang diperoleh melalui website BAZNAS terdapat strategistrategi yang telah dilakukan, yaitu :

1. BAZNAS melakukan penyaluran dana ZIS secara menyeluruh yang mencakup aspek-aspek penting baik dari segi spiritual, sosial maupun material. Total penyaluran terbesar yaitu pada bidang ekonomi sebanyak $42 \%$. Hal ini membuktikan bahwa saat ini, fokus utama BAZNAS adalah untuk menekan angka kemiskinan dengan cara pemberdayaan ekonomi mustahik sehingga dapat meningkatkan pertumbuhan ekonomi Indonesia.

2. BAZNAS juga mengadakan inovasi pada bidang penyaluran. Salah satu contohnya yaitu BAZNAS berkolaborasi dengan Departemen Ilmu Ekonomi Syariah FEM IPB dan Pemkot Bogor dalam pengembangan Kampung Batik Cibuluh, Kota Bogor, sebagai destinasi wisata batik nasional tahun 
2020 dan internasional tahun 2021. BAZNAS melakukan perubahan terhadap Kampung Cibuluh agar menjadi kawasan produsen batik yang memiliki nilai tambah terhadap produk yang dihasilkan. Program ini baru berjalan sekitar 6 bulan tetapi sudah terlihat peningkatannya dari segi perekonomian. Upaya yang dilakukan ini memberikan dampat yang positif terhadap pertumbuhan perekonomian Indonesia. Berdasarkan keterangan dari BAZNAS, upaya yang dilakukan ini juga memberikan dampak yang baik serta terjadi peningkatan perekonomian masyarakat di daerah tersebut

3. BAZNAS juga membentuk suatu Unit Saluran Zakat Center. Unit ini merupakan suatu program pembentukan unit penyaluran dana ZIS dalam bentuk penyaluran karitas (penyaluran dana langsung dalam bentuk pemenuhan kebutuhan pokok atau penyediaan layanan kepentingan umum).

4. BAZNAS juga membuat program yaitu dengan memberikan modal usaha dalam bentuk pinjaman atau dana hibah disektor UKM (usaha kecil menengah). Usaha pemberian modal usaha ini telah banyak dilakukan oleh berbagai lembaga, baik pemerintah maupun non pemerintah. Perbedaan program yang dibuat BAZNAS yaitu program bantuan modal bagi UKM yang dipadukan dengan pembinaan mental agama.

\section{KESIMPULAN}

Berdasarkan hasil penelitian yang telah dijelaskan di bab sebelumnya, maka kesimpulan yang diperoleh dalam penelitian ini adalah :

1. Penyaluran Dana ZIS secara parsial berpengaruh positif terhadap pertumbuhan ekonomi di Indonesia pada periode 2015-2019. Hasil analisis dana ZIS sebesar 0,155 yang artinya apabila perubahan dana ZIS naik 1 maka terjadi perubahan pertumbuhan ekonomi akan bergerak kearah yang sama (naik) sebesar 0,155 .

2. Tingkat inflasi tidak berpengaruh secara parsial terhadap pertumbuhan ekonomi di Indonesia pada periode 2015-2019. Hasil analisis inflasi sebesar - 0,620 yang artinya apabila perubahan inflasi naik 1 maka terjadi perubahan pertumbuhan ekonomi akan bergerak kearah yang berbeda (turun) sebesar 0,620. Penyaluran dana ZIS serta tingkat inflasi berpengaruh secara simultan/serempak terhadap

\section{DAFTAR PUSTAKA}

Arif, Masykur. 2018. Hidup berkah dengan sedekah. Yogyakarta : KAKTUS

Arsyad, Lincolin. 2010. Ekonomi Pembangunan Edisi Kelima. Yogyakarta: STIM YKPN.

Ghofar, Abdul. 2010. Fiqih Wanita. Jakarta: Pustaka Al- Kautsar.

Ghozali, I. 2013. Aplikasi Analisis Multivariate dengan program SPSS Edisi ketujuh. Semarang: Badan Penerbit Unversitas Diponegoro.

Hadzig, M. Fuad. 2019. Ekonomi ZISWAF. Tangerang Selatan: Universitas Terbuka.

Karim, Adiwarman. 2015. Ekonomi Makro Islam. Depok : PT. Rajagrafindo Persada.

Madani, El. 2013. Fiqih Zakat Lengkap. Yogjakarta: DIVA Press.

Naf'an. 2014. Ekonomi Makro Tinjauan Ekonomi Syari'ah. Yogyakarta: Graha Ilmu.

Sugiyono. 2013. Statistika untuk penelitian. Bandung: Alfabeta.

Sugiyono. 2014. Metode Penelitian Kuantitatif, kualitatif dan $R \& D$. Bandung: Alfabeta.

Sugiyono. 2015. Metode Penelitian dan Pengembangan, Research and Development, Untuk Bidang: Pendidikan, Manajemen, Sosial, Teknik. Bandung: Alfabeta.

Sugiyono. 2017. Metode Penelitian Kuantitatif, kualitatif dan $R \& D$. Bandung: Alfabeta.

Sugiyono. 2018. Metode Penelitian Kuantitatif, kualitatif dan $R \& D$. Bandung: Alfabeta.

Susanto, A. 2013. Sistem Informasi Akuntansi. Bandung: Lingga Jaya Sugiyono.

Zuhri, Saifudin. 2012. Zakat di Era Reformasi (Tata Kelola Baru). Semarang: Fakultas Tarbiyah IAIN Walisongo 


\section{LAMPIRAN}

Analisis deskriptif
\begin{tabular}{|c|c|c|c|}
\hline & Mean & $\begin{array}{c}\text { Std. } \\
\text { Deviation }\end{array}$ & $\mathrm{N}$ \\
\hline & & 1,57906223 & 60 \\
PDB_Y & 13,155472 & 3 & 68 \\
ZIS_X1 & 8,8906634 & 7,38809902 & 60 \\
Inflasi_ &, 2608 &, 31586 & 60 \\
X2 &, 268 stive Statistics \\
\hline
\end{tabular}

\section{Histogram}

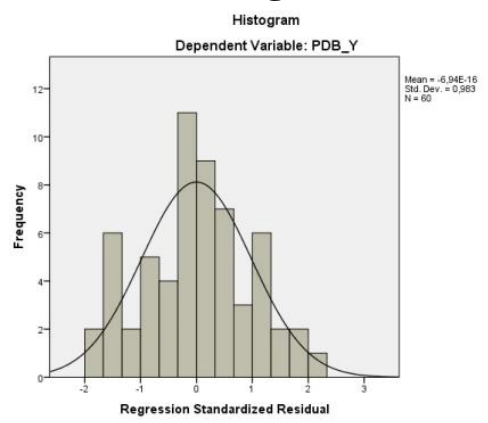

Uji normalitas metode one kolmogorov-smirnov One-Sample Kolmogorov-Smirnov Test

\begin{tabular}{|ll|l|}
\hline & & $\begin{array}{l}\text { Unstandardized } \\
\text { Residual }\end{array}$ \\
\hline N & & 60 \\
Normal Parameters & Mean & $0 \mathrm{E}-7$ \\
& Std. & 1096280,77232 \\
& & 476 \\
Most Extreme Differences & Absolute &, 065 \\
& Positive &, 059 \\
Kolmogorov-Smirnov Z & Negative &,- 065 \\
Asymp. Sig. (2-tailed) & &, 503 \\
& &, 962 \\
\hline
\end{tabular}

\section{Uji normalitas metode P-P-Plot}

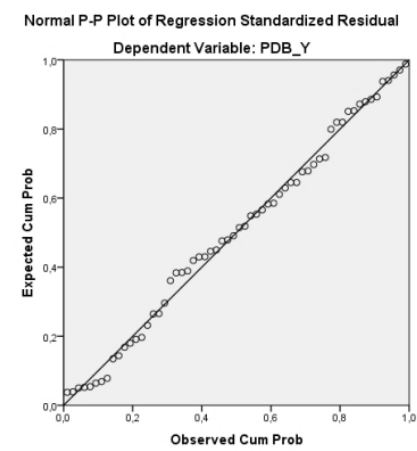




\section{Uji multikolinearitas}

\section{Coefficients $^{\mathrm{a}}$}

\begin{tabular}{|c|c|c|c|c|c|c|c|c|c|c|}
\hline \multirow[t]{2}{*}{ Model } & \multicolumn{2}{|c|}{$\begin{array}{l}\text { Unstandardized } \\
\text { Coefficients }\end{array}$} & \multirow{2}{*}{$\begin{array}{l}\text { Standard } \\
\text { ized } \\
\text { Coeffici } \\
\text { ents } \\
\text { Beta }\end{array}$} & \multirow[t]{2}{*}{$\mathrm{t}$} & \multirow[t]{2}{*}{ Sig. } & \multicolumn{3}{|c|}{ Correlations } & \multicolumn{2}{|c|}{$\begin{array}{l}\text { Collinearity } \\
\text { Statistics }\end{array}$} \\
\hline & B & $\begin{array}{l}\text { Std. } \\
\text { Error }\end{array}$ & & & & $\begin{array}{l}\text { Zero- } \\
\text { order }\end{array}$ & $\begin{array}{l}\text { Parti } \\
\text { al }\end{array}$ & Part & $\begin{array}{l}\text { Toler } \\
\text { ance }\end{array}$ & VIF \\
\hline $\begin{array}{l}\text { (Const } \\
\text { ant) }\end{array}$ & 11,940 & ,247 & & $\begin{array}{l}48,35 \\
4\end{array}$ & ,000 & & & & & \\
\hline $\begin{array}{ll}1 & \text { ZIS_X } \\
& 1\end{array}$ &, 155 & ,020 & ,725 & 7,819 & ,000 & ,709 & ,719 & ,719 & ,984 & $\begin{array}{l}1,01 \\
6\end{array}$ \\
\hline $\begin{array}{l}\text { Inflasi } \\
\text { X2 }\end{array}$ &,- 620 & ,463 &,- 124 & - & , 186 &,- 032 &,- 174 &,- 123 & ,984 & $\begin{array}{l}1,01 \\
6\end{array}$ \\
\hline
\end{tabular}

a. Dependent Variable: PDB_Y

\section{Uji heteroskedastisitas}

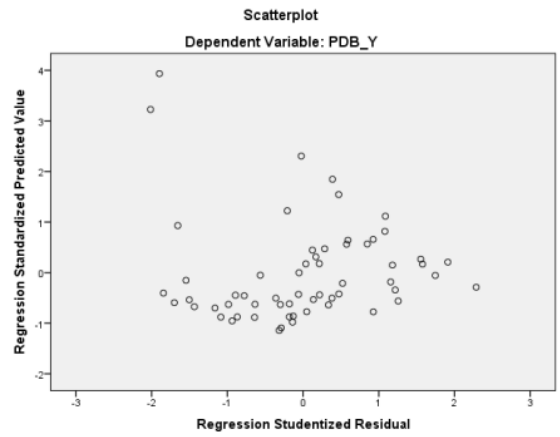

Uji Autokorelasi

Model Summary ${ }^{\mathrm{b}}$

\begin{tabular}{|c|c|c|c|c|c|c|c|c|c|}
\hline \multirow{2}{*}{$\begin{array}{l}\text { Mo } \\
\text { del }\end{array}$} & \multirow[t]{2}{*}{$\mathrm{R}$} & \multirow{2}{*}{$\begin{array}{c}\mathrm{R} \\
\text { Squ } \\
\text { are }\end{array}$} & \multirow{2}{*}{$\begin{array}{l}\text { Adj } \\
\text { uste } \\
\text { d R } \\
\text { Squ } \\
\text { are }\end{array}$} & \multicolumn{5}{|c|}{ Change Statistics } & \multirow{2}{*}{$\begin{array}{l}\text { Durbin- } \\
\text { Watson }\end{array}$} \\
\hline & & & & $\begin{array}{c}\mathrm{R} \\
\text { Squa } \\
\text { re } \\
\text { Chan } \\
\text { ge }\end{array}$ & $\begin{array}{c}\text { F } \\
\text { Chan } \\
\text { ge }\end{array}$ & $\begin{array}{c}\mathrm{df} \\
1\end{array}$ & df2 & $\begin{array}{l}\text { Sig. } \\
\text { F } \\
\text { Chan } \\
\text { ge }\end{array}$ & \\
\hline 1 & $\begin{array}{c}, 7 \\
20 \\
\mathrm{a}\end{array}$ & ,518 & ,501 & ,518 & $\begin{array}{c}30,6 \\
29\end{array}$ & 2 & 57 &, 000 & ,698 \\
\hline
\end{tabular}

a. Predictors: (Constant), Inflasi_X2, ZIS_X1

b. Dependent Variable: PDB_Y 


\section{Uji signifikasi parsial (Uji statistik t)}

Coefficients $^{\mathrm{a}}$

\begin{tabular}{|c|c|c|c|c|c|c|c|c|c|c|}
\hline \multirow[t]{2}{*}{ Model } & \multicolumn{2}{|c|}{$\begin{array}{l}\text { Unstandardized } \\
\text { Coefficients }\end{array}$} & \multirow{2}{*}{$\begin{array}{l}\text { Standard } \\
\text { ized } \\
\text { Coefficie } \\
\text { nts } \\
\text { Beta }\end{array}$} & \multirow[t]{2}{*}{$\mathrm{t}$} & \multirow[t]{2}{*}{ Sig. } & \multicolumn{3}{|c|}{ Correlations } & \multicolumn{2}{|c|}{$\begin{array}{l}\text { Collinearity } \\
\text { Statistics }\end{array}$} \\
\hline & B & $\begin{array}{l}\text { Std. } \\
\text { Error }\end{array}$ & & & & $\begin{array}{l}\text { Zero- } \\
\text { order }\end{array}$ & $\begin{array}{l}\text { Partia } \\
1\end{array}$ & Part & $\begin{array}{l}\text { Tolera } \\
\text { nce }\end{array}$ & VIF \\
\hline $\begin{array}{l}\text { (Const } \\
\text { ant) }\end{array}$ & 11,940 & ,247 & & $\begin{array}{l}48,35 \\
4\end{array}$ &, 000 & & & & & \\
\hline$\underset{1}{\text { ZIS_X }}$ &, 155 & ,020 &, 725 & 7,819 & ,000 & ,709 & ,719 & ,719 & ,984 & 1,016 \\
\hline $\begin{array}{l}\text { Inflasi } \\
\text { X2 }\end{array}$ &,- 620 & ,463 &,- 124 & $\begin{array}{l}- \\
1,338\end{array}$ & ,186 &,- 032 &,- 174 &,- 123 & ,984 & 1,016 \\
\hline
\end{tabular}

a. Dependent Variable: PDB_Y

Uji signifikansi simultan (Uji statistik F)

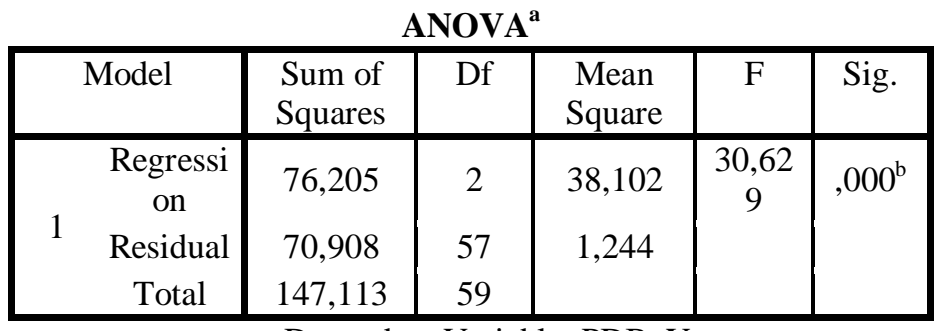

a. Dependent Variable: PDB_Y

b. Predictors: (Constant), Inflasi_X2, ZIS_X1 